\title{
The Effect of Thematic Classes on English Vocabulary Learning: A Study of Iranian Junior High School Students
}

\author{
Zeinab Mahmoudi \\ Department of English, Khorasan e Razavi Science and Research Branch, Islamic Azad University, Neyshabur, Iran \\ Department of English, Neyshabur Branch, Islamic Azad University, Neyshabur, Iran \\ E-mail: yas1811z@yahoo.com \\ Narjes Ghafournia (Corresponding author) \\ Department of English, Neyshabur Branch, Islamic Azad University, Neyshabur, Iran \\ E-mail: na.ghafournia@gmail.com
}

Received: 10-12-2015

Published: 01-05-2016
Accepted: 19-02-2016

doi:10.7575/aiac.ijalel.v.5n.3p.161
Advance Access Published: March 2016

URL: http://dx.doi.org/10.7575/aiac.ijalel.v.5n.3p.161

\begin{abstract}
This study was designed to verify the effect of thematic classes on English vocabulary learning. Thematic class is an educational project, which recently started to be used in junior high schools in Iran. The ministry of Education in Iran has launched the project of thematic classes to improve learning in 2010 with the hope of copying with some of the educational problems so that students experience deeper learning. For subjects of the study, 907 th grade students of junior high school in Taybad, Khorasan e Razavi were selected. Three groups were used in this study: two experimental groups and one control group. Each group consisted of 30 female students, who settled randomly in the groups, respectively. Their range of age was between 13 and 14. A vocabulary-based test, which was designed by the researcher, was used as the main measurement tool in the study to evaluate the students' achievement in the course. The course lasted 10 weeks, two sessions per week. The results reflected the positive effect of thematic classes on vocabulary learning. Therefore, educational implication of thematic class for junior high school is suggestible.
\end{abstract}

Keywords: Thematic Class, Cooperative Learning, Vocabulary, Visual Aids, Audio Visual Aids, Motivation

\section{Introduction}

Due to the reality of global village in the 21 st century, English learning has been an important educational issue in Asia. Thus, English has been included in the curriculum of junior high schools in Iran. It means that Iranian students start learning English at age 13 or 14 through formal instructions. Even, many parents enroll their children in English institutes in earlier ages. On the other hand, since there is not enough English input in Iran, it brings about some difficulties for Iranian students to learn English.

Vocabulary plays a major role in learning a foreign language (Filinezhad, Jamali Nesari \& Karimi, 2011; Mediha \& Enisa, 2014). Krashen (1987) believes that "while knowledge of vocabulary may not be sufficient for understanding all messages, there is little doubt that an increased vocabulary helps the acquirer understand more of what is heard or read" (p. 80). Learning vocabulary is the most important challenge in language teaching process (Mediha \& Enisa, 2014). As Croll (1971) mentioned, teaching English vocabulary is difficult and boring for teachers. Furthermore, beginners find it boring and difficult to memorize long lists of new words with their mother tongue equivalents as they are taught orally in most English classes. They are always afraid of forgetting them soon. Iranian students, like any other foreign language learners, are supposed to improve their vocabulary as part of their learning English. However, since they are not exposed to enough vocabulary input, both teachers and students find it rather difficult to deal with it efficiently.

Students in schools are losing their motivation to learn English. Therefore, curriculum planners and teachers always try to find ways to attract students' attention and make them motivated as much as possible. Using educational aids is one way to facilitate language learning. Teaching aids arouse the interest of learners and help teachers to explain the concepts easily (Rasul, Bukhsh \& Batool, 2011).

Iran Ministry of education in 2010 has propounded the importance of thematic classes for junior high schools. The aim of thematic classes is to assist learners and teachers in order to encourage cooperative learning, motivation, and maximum use of educational aids. It causes the alteration of teacher-oriented into student-oriented method. It is predicted that this project will lead to improved learning process. Thematic classes are designed to instruct a very specific subject matter such as mathematics, Quran, and English language. In other words, teachers who make the ultimate use of the educational aids in classes aim at providing specific teaching equipment. In thematic class project, the teacher and class are fixed, and students change their classroom according to their programs. In sum, different aims of thematic classes are as follows:

- To improve the quality of education in schools.

- To convey the educational concepts to learners better than before. 
- To help learners for easier and faster learning.

- To motivate the learners and increase the depth of learning and retention.

- To provide an environment for both theoretical and operational activities.

It was aimed to answer the following questions in this study:

1. Does thematic class of English without audio visual aids have any significant effect on English vocabulary learning?

2. Does thematic class of English with audio visual aids have any significant effect on English vocabulary learning? The relevant null hypotheses were formulated as follows:

1. Thematic class of English without audio visual aids has not any significant effect on English vocabulary learning.

2. Thematic class of English with audio visual aids has not any significant effect on English vocabulary learning.

\section{Review of Literature}

Many theoretical and empirical studies have been done on the importance of vocabulary knowledge in second and foreign language learning. The results of Daller and Phelan (2007, pp. 234-235) suggest that "in an educational setting, the advanced parts of the lexicon play a crucial role in the construct of foreign language proficiency." New words should not be presented in isolation and should not be learned by simple rote memorization (Davies \& Pears, 2003). If teachers present new words in isolation, they will be forgotten soon, and students will become tired. There are a lot of studies, which have examined different ways to improve English vocabulary learning as a foreign language (e.g. Allahverdi \& Gholami, 2014; Lawson \& Hogben, 1996). The learners' proficiency level and educational goals should be taken into consideration when deciding how to teach vocabulary.

\subsection{Thematic Class}

The ability to integrate different modes of presentation is an improvement over traditional education and the ability to use multimedia results in an enriched learning environment (Reinders \& White, 2010, p.66). Thematic class is designed for efficient use of educational aids, cooperative learning, development of motivation, creativity and innovation, and facilitating teaching and learning process for students of junior high school in Iran. In this project, teacher and classroom are fixed, and students are changed according to their own weekly curriculum. It is hoped that thematic classes facilitate learning by accessing different ways for presenting subject matters and make learning more attractive. Another main aim of thematic classes is to improve the quality of teaching and learning processes. Quality teaching is achieved not only as a consequence of how well teachers teach but through creating contexts and work environments that can facilitate good teaching (Richards, 2009). It is imagined that thematic class includes all kinds of learning styles. There is a great deal of evidence that a mismatch between students' learning styles and teacher's instructional style may have a negative impact on classroom learning (Felder \& Henriques, 1995; Mulalic, Mohd Shah \& Ahmad, 2009). So, if teachers try to use thematic class with its real characteristics, it will be more useful for different students with various learning styles in the class.

The students who learn English as a foreign language do not have not any opportunities to contact with native speakers or be in real environment of English. On the other hand, they need to review and practice English language continuously. A thematic class can be a small sample of real world related to the subject of that class. For example, thematic class of English should be a small sample of real English environment. Everything in it should be related to English language: pictures, films, teachers' spoken language, charts, and etc. Teachers can provide animations, video clips with English language, and also they can increase the opportunities for reviewing the new materials by providing related pictures and wall charts in a thematic class. In this case, they can always see them and review the materials unconsciously.

According to Richards (2009), there are two kinds of materials: Authentic materials and created materials. The first one refers to the use of texts, photographs, video selections, and other teaching resources that are not specially prepared for pedagogical purposes. The second one refers to textbooks and other specially developed instructional resources (p. 252). In many language programs, teachers use a mixture of created and authentic materials because both have their advantages as well as limitations (Richards, p. 253). Teachers can use a combination of them to improve learning and teaching processes.

Teachers need to provide a variety of language learning activities, which allow for different learning styles and individual preferences and personalities: some visual, some auditory, some involving movement, some interactive and some analytic (Williams \& Berden, 2000, p.205). Thematic class can provide ample situations for various types of learning styles.

\subsubsection{Thematic Class and Peripheral/Incidental Learning}

Thematic classes sometimes result in peripheral learning. The word peripheral can be considered synonymous with words like: unimportant, minor, secondary, and marginal. Therefore, peripheral learning can be defined as learning from the environment where the students are present in. "Peripheral" learning is encouraged through the presence of posters and decorations in the learning environment featuring the target language and different grammatical information. Students can absorb information "effortlessly" when it is perceived as part of the environment, rather than the material "to be attended to (Fatemipour, 2013). It is hoped that the special form of thematic class helps enhancing peripheral learning.

In addition, thematic class of English may be an effort to increase incidental learning of different areas of English especially in vocabulary learning. Incidental language learning has been defined by Laufer and Hulstijn (2001, p. 10; cf. Schmidt, 1994) as "the learning without an intent to learn, or as the learning of one thing, e.g. vocabulary, when the 
learner's primary objective is to do something else, e.g. to communicate." The students' attendance at thematic class may lead to incidental learning.

\subsection{Educational Aids}

It has long been a concern to use educational aids in language teaching. Exchanging the information will be more understandable, relevant, and interesting for students via educational aids. Students pay more attention to the material when they are presented through educational aids. Educational aids are not necessarily expensive and complex. They can be very simple and can be made as cheap as possible. Selecting the type of educational aids depends on the instructional goals and learners' level of proficiency.

\subsubsection{Visual Aids}

Many teachers try to apply pictures and other visual aids in learning and teaching processes to create an interesting classroom for their students. Varieties of visual aids are large. They may be in the form of charts, pictures, graphics, slides, flash cards, and etc. Levin, Anglin and Carney (1987) reported that pictures facilitate long-term memory by creating a memorable mnemonic. Charts are larger sheets of card or paper, which include writing, pictures, or diagrams that are used for more extended presentation. Flash cards are another type of visual aids. Doff (2004, p. 83) defined them as cards with single pictures, which can be held up by the teacher. Graphics are used as educational aids too. Graphics may be static or animated. Graphics can represent important information, and they are often used to support visual text (Newby, Stepich, Lehman, \& Russel, 1996).

Doff (2004) believes that using visual aids make the class more interesting and help to make the language used in the class more real and alive. Mayer and Sims (1994) stated that one of the functions of a multimedia program is to help learners construct referential connections between two forms of mental representation systems: the verbal and the visual one. These referential connections are more easily built when both verbal and visual materials are presented simultaneously.

There is significant evidence that generally memory for pictures is better than memory for words. This consistent finding is referred to as the picture superiority effect. There are three important theoretical perspectives, which have been used to explain the picture superiority effect (Jonassen, 2008):

a) The dual-code model: According to this model, there are two interdependent kinds of memory codes for processing and storing information. The first one is verbal code, which is used for processing and storing verbal information such as words and sentences. The second one is nonverbal code, which includes memory for all nonverbal phenomena. This type is used for images and other picture-like representations. The single-code model: Based on this model, visual information is transformed into abstract propositions stored in semantic memory (Rieber, 1994; Shepard, 1978). Proponents of this model argue that pictures activate a single semantic memory system more differently than do words.Sensory-semantic model: There may be a more distinctive sensory code for pictures and the probability that pictures will be processed semantically is greater than for words (Nelson, Reed, \& Walling, 1976). If teachers use comical pictures, they will affect students' feeling, will make learning more interesting, and will make classroom atmosphere more enjoyable.

2.2.2 Audio Visual Aids

In traditional learning, printed materials were the main educational materials (Nili \& Altafi Dadgar, 2011, p.32). Nowadays, the kinds and numbers of educational aids have been varied by development of technology. Electronic devices and much software and hardware can be applied as educational aids in instructional contexts. Singh (2005) states that any devices, which by sight and sounds increase the individuals' experience, can be described as an audiovisual aids. In classrooms where teachers use different modes of presentation via multimedia and audio-visual aids, they may establish a match between students' needs, different learning styles, and kinds of modes of presentation. The combination of media enhances learning because words are dually coded resulting in referential connections that are constructed between the verbal and visual systems (Al-Seghayer, 2001).Among various authentic audio-visual sources of language input, cartoons are among the most pedagogic and valuable sources, which can be used as useful means of improving the learning atmosphere (Bahrani \& Soltani, 2011). This is in line with the study conducted by Rule and Ague (2005), which indicates that cartoons are preferred by language learners because they create low affective filter atmosphere, which causes high degree of motivation.

Audio visual aids motivate students because they can reflect native like language in the classroom and change the classroom atmosphere. As mentioned before, for foreign language learners, who do not have any chances to communicate with native speakers of English, it is considered as an advantage to use audio visual aids.Language learning strategies are divided into two categories: direct learning strategies and indirect learning strategies. The operations concerned with memorizing, including rules, guessing meaning, and rehearsal contribute directly to the learning of the language at a cognitive level, which are set in the first group of learning strategies. Indirect learning strategies are those processes that are used to learn a foreign language by bringing individuals into closer contact with the target language (Williams \& Burden, 2000). Audio visual aids give students great opportunities to reinforce indirect strategies for learning a foreign language where there is rarely a chance to contact with native speakers of that language. In countries, like Iran, that there is a rare chance to meet native speakers of English, providing opportunities to listen to the English words and sentences spoken by native speakers of that language is very important for students and other language learners.

\subsection{Cooperative Learning and Group Working}

In traditional methods of teaching, students were passive listeners. They had to listen to the teacher and do everything she/he asked them. This method was boring for students because the classroom was changed into a lecture room, and 
students had to sit on their chairs without any activity and just listen to the teacher. But nowadays teachers' monotonous speech has become a tradition. In new methods of teaching, teachers are as leaders, who try to guide and control their students' activities.

Keramati (2005) believes that successful class is one that eighty percent of its speaking time is devoted to students and twenty percent is for teachers. An effective way to persuade students to speak in class is using cooperative learning. In cooperative learning, students directly participate in learning and have active interaction in teaching (Cohen, 1994). Cooperative learning is a teaching model in language teaching programs. In this model, students work in cooperative learning situations and are encouraged to work together on common tasks and coordinate their efforts to complete tasks (Richards, 2009, p.215). Olsen and Kagan (1992, p 256) have defined cooperative learning as " group learning activity organized so that learning is dependent on the socially structured exchange of information between learners in groups in which each learner is held accountable for his/ her own learning and is motivated to increase the learning of others".

Cooperative learning is useful for all students regardless of race, sex, age, and level of knowledge. May (2000) believed that cooperative learning is applicable even in crowded classrooms, and it has had positive effect on learning. Also, it can be said that cooperative learning method is suitable for all kinds of subject materials such as subjects that need problem solving, those which need creative responses, or those subjects that are theoretical.

Another benefit of cooperative learning for students is that they sometimes cannot understand teachers' explanation and if their classmate explains the same subject to them, they may get the main point better. Slavin (1987) believes that students are often able to translate the teacher's language into "kid language" for one another. Cooperative learning focuses on collaborating and partnership. Students learn and work in different groups, and they are responsible for their own learning and also for others' learning. They help each other to achieve their goals. Cooperative learning results in creativity and deep learning (Shafer, 2002).

In group working, typical group size is from two to four, but in different classrooms, it depends on the task that students have to carry out, the learners' age, and time limits for the lesson (Richard \& Rodgers, 2001). Salvin (1987) states the groups usually have four members: one high achiever, two average achievers, and one low achiever. Heterogeneous groups will be more efficient. In behaviorism view, there is an effort to make the learners as homogenous as possible. But in constructivism view, individuals' differences are considered more than other views (Aghazadeh, 2006, p.41).

\subsection{Motivation}

Motivation refers to a combination of effort plus desire to achieve the goal of learning the language plus favorable attitudes towards learning the language (Williams \& Burden, 2000, p.116). Second language motivation is an important factor, which helps learners to improve their learning. L2 motivation generally refers to the direction and magnitude of human behavior, including the choice of a particular action, the persistence with it and effort expended on it (Dornyei \& Skehan, 2003). Olive (1972) stated that students are motivated to learn when they deal with materials geared to their level and work with interesting materials. They also have some opportunity to make decision, enter into the planning, and feel responsibility for participating.

A cognitive definition of motivation, which fits within a social constructivist framework states that motivation may be constructed as a state of cognitive and emotional arousal. It leads to a conscious decision to act, which gives rise to a period of sustained intellectual or physical effort in order to attain a previously set goal (Williams \& Burden, 2000, p.120). Based on this definition, the initial arousal may be created by different causes such as interest, goal, encouragement by other people, or even by force.

According to Williams and Burden (2000), there are two different types of motivation: intrinsic and extrinsic motivation. When individuals do something because the act of doing it is enjoyable in itself, they have intrinsic motivation. On the other hands, some individuals have extrinsic motivation. They do an activity not because they are interested in the activity itself, but because doing it will help them to obtain another thing that they want.

In the present study, thematic class environment can be an initial arousal and encouragement for students. But it is not enough. When initial interest and activation are created, it should be sustained to achieve the final goals and aims. In a thematic class, cooperative groups and continuous use of educational aids may be effective for sustaining the initial arousal.

It is hoped that thematic class environment will be so interesting that can enhance students and finally increase their intrinsic motivation. Thematic class should make a supportive learning environment. When a context is supportive and fosters the learners' will to learn, individuals are encouraged to express themselves and develop their full potential. Thus, this supportive learning environment creates powerful motivating conditions (Williams \& Burden, 2000, p.142).

\subsection{Related Studies}

Kost, Foss, and Lenzini (1999) carried out a study comparing the effects of pictorial and textual glosses on incidental vocabulary growth for foreign language learners. Performance on both production and recognition tests of 14 words was better for those who were allowed to use a combination of text and picture. In a critical analysis of L2 vocabulary learning techniques, Oxford and Crookall (1990) stated that most learners are capable of associating new information to concepts in memory by means of meaningful visual images that make learning more efficient. In a study done by Snyder and Colon (1988) the influence of both audio and visual aids on facilitating second language acquisition was investigated. The findings showed that the group provided with additional audio-visual aids performed significantly better in vocabulary retention. In another study on the effectiveness of audio-visual aids in teaching learning process, the following results were obtained (Rasul \& Bukhsh \& Batool, 2011): 
- The students viewed that audio-visual aids play important role in teaching learning process.

- They make teaching learning process effective.

- The students viewed that audio-visual aids provide knowledge in depth and detail.

- It brings change in classroom environment.

- It motivates teachers and students.

In a study on implementing cooperative learning in the language classroom, opinions of Turkish teachers of English were investigated (Celik, Aytin, \& Bayram, 2013). Results of this study reveal that students' anxiety has been reduced in group working, and they may learn more readily from other students than from their teacher. Finding of some other studies have indicated that educational success, self-respect, and friendly relations between members of group are the results of cooperative learning (Keramati, 2005). In a study carried out by Baleghzadeh (2012), traditional and cooperative pairs were compared with each other. The results of this study showed that participants who formed cooperative pairs significantly outperformed those who formed traditional pairs. This indicates that pair work will be more effective and maximize further learning when students learn how they must cooperate with each other.

In the motivation area, Eisenberger, Pierce, and Cameron (1999) developed general interest theory. This theory states that the content of tasks and activities and the context in which they are presented enhance intrinsic motivation and helps satisfying the needs, wants and desires. Jovanovich and Matejevic (2014) believe that creating an environment that encourages the development of situational interest is one of the ways in which schools can encourage students' motivation, which helps students to achieve cognitive benefits in the areas which they are attracted to at first. Rovai, Ponton, Wighting, and Baker (2007) studied on Students' Motivation in Traditional Classroom and E-Learning Courses. The results give evidence that the students who are taught by e-learning are more intrinsically motivated than the students who go to Traditional Classroom. They found that there were no differences in extrinsic motivation.

\section{Methodology}

\subsection{Participants}

The population of this study was selected from Zeinab junior high school in Taybad, Khorasan e Razavi, Iran. Participants of current study were selected from 120 students, who were in seventh grade. All of them were female and were aged between 13 and 14 years old. They were at beginner level of language proficiency because seventh grade is the first year that students study English in public schools in Iran. Generally, all participants of the study matched each other in grade, school, native language, gender, English teacher, neighborhood, and cultural background.

To achieve the purposes of the study, it was required to have three groups: one control group and two experimental groups. Therefore, it was necessary to have homogenous students in all three groups. For this reason, all the seventh grade students, who had studied English in different institutes out of school, were separated. Then, based on their scores on a Standard English test, a total of 90 students were selected as the main sample of the study. Random assignment was used to form the three groups. Thirty students were placed in each group.

\subsection{Instrumentation}

In a current study, a standard test of Khate Sefid (the name of a standard test book) was used to select homogenous sample for two experimental groups and one control group. This test examined the students' general knowledge of English. The test included 36 items. To evaluate the effect of different types of thematic classes on English vocabulary learning, a vocabulary-based test was used through two phases: one time before instruction as a pre-test and one time after instruction as a post-test. The vocabulary-based test was designed by the researcher. The test included thirty items, which targeted students' vocabulary knowledge. There were various kinds of items in the test, but all of them were objective. Filling the blanks, matching the words with pictures, grouping the words, multiple choice items, and writing the appropriate words were the most frequent items in the test. To remove probable ambiguities, instructions of the items were written in Persian, the participants' mother tongue. For the total test performance, scores were tabulated out of 30. Every item was graded dichotomously. In other words one score was given for every correct answer, and one zero score was given for an incorrect answer. Duration of the test was 45 minutes. The test was given to some EFL teachers, who provide useful feedback on the content of the test. Then, it was piloted on 30 students, who were similar to the participants of the study. Finally, necessary revisions were made by the researcher to improve the content validity of the test. To assess the reliability of the test, Kuder-Richardson Formula 21 was utilized. The reliability index was $\mathrm{a}=0.839$, which was high and acceptable.

\subsection{Procedure}

For the purposes of this study, it was required to have two experimental groups and one control group. Based on the extent and kinds of educational aids, thematic classes of English were divided into two types. Each type of classes was set as an experimental group: first type and second type of thematic class.

In the first type of thematic class, educational aids were limited to pictures, photos, flashcards, real objects, and signs. Students of this group had not any auditory and listening aids, by which they can profit. In the second type of thematic class, there was a data projector in addition to pictures, photos, flashcards, and signs. In this class, students could listen to the native pronunciation of words. Teacher used the combination of image and sound for presenting new materials. Students of this experimental group received new words through animation, slides, and other dynamic images. They sometimes listened to a native voice that pronounced the word related to a static image. Both experimental groups shared in cooperative learning situation by arranging cooperative groups. Students of experimental groups were arranged in six groups according to their general English knowledge. The members of each group were selected by the teacher. Each group had five heterogeneous members: one high achiever, two average achievers, and two low achievers. 
They tried to help each other learn new materials. Group score was given to all members of the group after they did activities.

In control group, there were not any educational aids except the usual ones like students' books and a blackboard. Teacher presented new materials in a traditional way in this class. Teacher read new words and students are asked to repeat them. After that, they should write Persian equivalents of new words and memorize them. There was not any cooperative group in this group.

Initially, those seventh grade students, who had studied English in English institutes outside of school, were separated. Then, a standard test of Khate Sefid was administered to the rest of the students. Ninety students, who located one standard deviation above and below the mean, were selected as the sample of the study. They were assigned into three groups randomly. Each group contained thirty students. The researcher was the teacher of the three groups. All three groups had the same number of hours of instruction. It lasted ten weeks, two sessions per week, and ninety minutes each session.

A researcher-made test was given to the participants of all three groups one week prior to the instruction as pre-test. The test contained thirty items, which evaluated students' vocabulary knowledge. Total score of test was 30, one point for each correct answer. Duration of the test was 45 minutes. At the end of instruction course, this test was administered to the participants as a post-test, in the same condition. Researcher compared the scores of pre-test and post-test for all three groups to find out the effect of different types of English thematic classes on vocabulary learning.

\subsection{Design and Data Analysis}

As a cause and effect relationship was explored, and the participants of the study were selected randomly, the design of the study was experimental. To achieve the results of the study, a set of parametric statistical analyses such as descriptive statistics, one-way analysis of variance, and a Tukey HSD test were utilized in the study.

\section{Results and Discussion \\ 4.1 Participants' Homogenization}

The aim of present study was to investigate the effect of different types of English thematic class on Iranian seventh grade students' vocabulary learning. A one-way analysis of variances was run to answer the research questions. Before discussing the results, it has been required to have homogenous participants in all three groups.

Usually, homogenization of the test scores using the confidence interval with one standard deviation above and below the mean is considered as a scientific measure for homogenizing the participants in pedagogic settings.

As such, the scores of Khate Sefid test were examined before and after homogenizing the test descriptively.

Table 4.1 Descriptive Statistics for Test Scores before and after Homogeneity

\begin{tabular}{lrr} 
& $\begin{array}{c}\text { Khate Sefid Test Scores } \\
\text { before Homogeneity }\end{array}$ & $\begin{array}{r}\text { Khate Sefid Test Scores after } \\
\text { Homogeneity }\end{array}$ \\
\hline Valid & 120 & 90 \\
Missing & 0 & 30 \\
Mean & 13.8422 & 14.40 \\
Std. Error of Mean & .28024 & .132 \\
Median & 14.0000 & 14.00 \\
Mode & 14.00 & 14 \\
Std. Deviation & 3.06985 & 1.250 \\
Variance & 9.424 & 1.562 \\
Skewness & -1.353 & -.302 \\
Std. Error of Skewness & .221 & .254 \\
Kurtosis & 2.232 & -.727 \\
Std. Error of Kurtosis & .438 & .503 \\
Range & 16.00 & 4 \\
Minimum & 2.00 & 12 \\
Maximum & 18.00 & 16 \\
Sum & 1661.06 & 1296 \\
Percentiles & 13.0000 & 14.00 \\
& 14.0000 & 14.00 \\
& 16.0000 & 16.00 \\
\hline
\end{tabular}

As Table 4.1 shows, the mean scores before and after the homogenization were 13.84 and 14.4, respectively, which they were very close together and could not be seen as a significant change. It means that homogenization did not cause a significant change in data mean. But the values of standard deviation for the scores before and after homogenization were respectively, 3.07 and 1.25. It means that the value of standard deviation has significantly reduced. In other words, homogeneity has strongly caused the reduction of standard deviation or score dispersion that is considered the main goal of homogenization. In other words, homogenization had been done properly in this section. 
A one-way analysis of variances was run to compare the mean scores of three groups on the pretest of vocabulary-based test in order to prove that they enjoyed the same level of vocabulary knowledge prior to the instruction. Table 4.2 showed descriptive statistics of the three groups in the pre-test.

Table 4.2 Descriptive Statistics of Vocabulary-based Pre-test

\begin{tabular}{lcccc}
\hline & $\mathrm{N}$ & Mean & Std. Deviation & Std. Error \\
\hline Control Group & 30 & 14.87 & 4.981 & .909 \\
First Type of Thematic Class (V Aids) & 30 & 15.40 & 5.506 & 1.00 \\
Second Type of Thematic Class (A.V Aids) & 30 & 15.57 & 5.917 & 1.08 \\
\hline
\end{tabular}

V Aids $=$ Visual Aids, A.V Aids = Audio Visual Aids, Control Group = Traditional Class

As displayed in Table 4.2, all three groups achieved similar means on pretest. The means of the three groups in the pretest are shown in Figure 4.1.

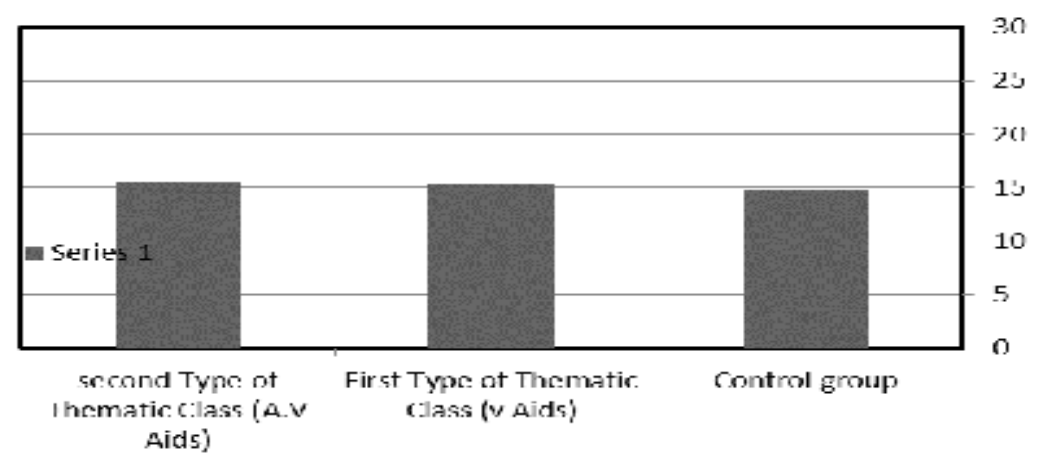

Figure 4.1 Pretest Means of Vocabulary-based Test

Figure 4.1 demonstrated that the mean scores of the three groups were close together and not significantly different. To explore the differences among the mean scores of the three groups, a one-way ANOVA was conducted. The results are shown in Table 4.3.

Table 4.3 ANOVA for Comparing Means of Groups in Pretest

\begin{tabular}{cccccc}
\hline & Sum of Squares & df & Mean Square & F & Sig. \\
\hline Between Groups & 8.022 & 2 & 4.011 & .133 & .875 \\
Within Groups & 2614.033 & 87 & 30.046 & & \\
Total & 2622.056 & 89 & & & \\
\hline
\end{tabular}

The results indicated that there were not any significant differences among the means of the three groups on the pretest. Thus, the three groups were homogeneous, and all the participants enjoyed nearly the same level of vocabulary knowledge before the instruction.

\subsection{Post-test of Vocabulary-Based Test}

Before discussing the results, it should be mentioned that the groups enjoyed homogenous variances on the posttest. As it is indicated in Table 4.4, the Levene's F-value of 4.81 was not significant $(\mathrm{P}<.05)$.

\begin{tabular}{cccc}
\multicolumn{4}{c}{ Table 4.4 Test of Homogeneity of Variances in Posttest } \\
\hline Levene Statistic & df1 & df2 & Sig. \\
\hline 4.810 & 2 & 87 & .010 \\
\hline
\end{tabular}

Table 4.5 displayed the descriptive statistics of the three groups in the posttest of vocabulary-based test.

Table 4.5 Descriptive Statistics of Vocabulary-based Posttest

\begin{tabular}{lcccc}
\hline & $\mathrm{N}$ & Mean & Std. Deviation & Std. Error \\
\hline Control Group & & & & \\
\hline First Type of Thematic Class (V Aids) & 30 & 23.10 & 4.69 & .85 \\
\hline Second Type of Thematic Class (A.V Aids) & 30 & 24.90 & 4.37 & .79 \\
\hline Total & 90 & 22.28 & 5.71 & .60 \\
\hline
\end{tabular}

V Aids $=$ Visual Aids, A.V Aids $=$ Audio Visual Aids, Control Group $=$ Traditional Class 
The second type of thematic class (A.V aids) $(M=24.90, \mathrm{SD}=4.37)$ showed the highest mean score in the posttest. This was followed by the first type of thematic class (V aids) $(M=23.10, \mathrm{SD}=4.69)$ successively. The control group showed the lowest mean score $(M=18.86, S D=6.26)$. The results of one-way ANOVA presented a large effect size, indicating significant differences among the means of three groups in posttest. The results are shown in Table 4.6.

Table 4.6 ANOVA for Comparing the Mean Scores

\begin{tabular}{cccccc}
\hline & Sum of Squares & df & Mean Square & F & Sig. \\
\hline Between Groups & 575.622 & 2 & 287.811 & 10.733 & .0001 \\
Within Groups & 2332.867 & 87 & 26.815 & & \\
Total & 2908.489 & 89 & & & \\
\hline
\end{tabular}

As shown in Table 4.6, F-value of 10.73 at $\mathrm{p}=.0001$ indicated significant differences among the means of all groups. A Tukey HSD was run to compare the mean scores of the groups in order to probe the research questions. The results are shown in Table 4.7.

Table 4.7 Multiple Comparisons of Vocabulary Scores in Posttest Using Tukey HSD

\begin{tabular}{|c|c|c|c|c|}
\hline (I) group & (J) group & $\begin{array}{c}\text { Mean Difference } \\
(\mathrm{I}-\mathrm{J})\end{array}$ & Std. Error & Sig. \\
\hline \multirow[t]{2}{*}{ Control Group } & $\begin{array}{l}\text { first type of thematic class } \\
\text { (V aids) }\end{array}$ & $-4.23333^{*}$ & 1.33703 & .006 \\
\hline & $\begin{array}{l}\text { second type of thematic class } \\
\text { (A.V aids) }\end{array}$ & $-6.03333^{*}$ & 1.33703 & .000 \\
\hline $\begin{array}{l}\text { first type of thematic } \\
\text { class(V aids) }\end{array}$ & $\begin{array}{l}\text { Control Group } \\
\text { second type of thematic class } \\
\text { (A.V aids) }\end{array}$ & $\begin{array}{l}4.23333^{*} \\
-1.80000\end{array}$ & $\begin{array}{l}1.33703 \\
1.33703\end{array}$ & $\begin{array}{l}.006 \\
.374\end{array}$ \\
\hline $\begin{array}{l}\text { second type of thematic } \\
\text { class (A.V aids) }\end{array}$ & $\begin{array}{l}\text { Control Group } \\
\text { first type of thematic class } \\
\text { (V aids) }\end{array}$ & $\begin{array}{c}6.03333^{*} \\
1.80000\end{array}$ & $\begin{array}{l}1.33703 \\
1.33703\end{array}$ & $\begin{array}{l}.000 \\
.374\end{array}$ \\
\hline
\end{tabular}

The results indicated that there was a significance difference between first type of thematic class (V aids) and control group $(\mathrm{MD}=4.23, \mathrm{P}<.05)$. Based on the results, the first null-hypothesis - thematic class of English without audio visual aids had not any significant effect on English vocabulary learning- was strongly rejected. First type of thematic class group also outperformed the control group on the posttest. There was a significant difference between second type of thematic class (A.V aids) and control group $(\mathrm{MD}=6.03, \mathrm{P}<.05)$. So, the second null-hypothesis - thematic class of English with audio visual aids had not any significant effect on English vocabulary learning- was strongly rejected, too. Second type of thematic class group also outperformed the control group on the posttest of vocabularybased test. There was not any significant difference between two types of thematic class $(\mathrm{MD}=1.80, \mathrm{P}<.05)$. Figure 4.2 shows the mean scores of the three groups in the posttest.

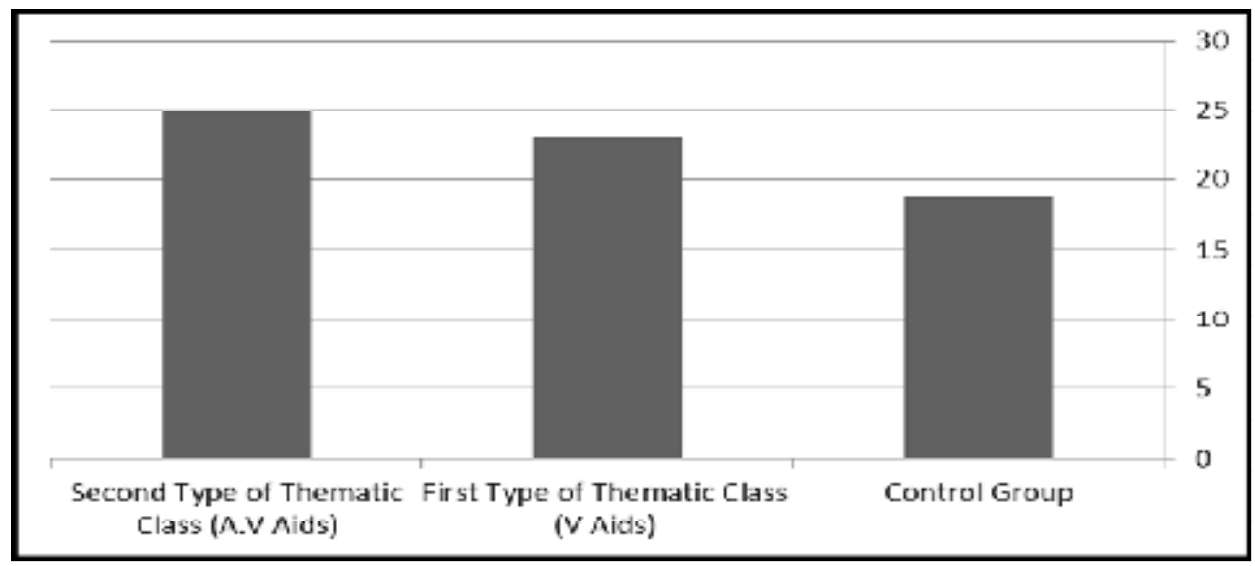

Figure 4.2 Posttest Means of Vocabulary-based Test

As demonstrated in Figure 4.2, the mean scores of two types of thematic class had been higher than the mean score of control group in posttest vocabulary-based test. 


\subsection{Discussion}

Latragna (1997) indicated similar findings, where he found that the students in his study had more preference for a nontraditional learning style, cooperative learning, and student-centered instruction. The findings of this study are in line with Brown's (1993) findings in that word learning is facilitated when concept is taught in the form of an image before the word-form appeared. In addition, the findings of this study are in accordance with Kost, Foss, and Lenzini's (1999) findings. They proved that EFL learners performed better on both production and recognition vocabulary tests when they were allowed to use a combination of visual texts and graphics. In audio-visual area, the results of this study are supported by Synder and Colon's results. They (1988) verified that students performed significantly better in vocabulary retention when they are provided with additional audio visual aids. In addition, the findings of the present study match the Al-Seghayer's (2001) findings. The results of his study indicated that video better helps learners build a mental image, curiosity increases concentration, and video's combination of modalities (dynamic image and sound) facilitates recall.

Cooperative learning is another characteristic of thematic class. The findings of this study also agree with the findings of Baleghzade (2012), where he found that participants who formed cooperative pairs significantly outperformed those who formed traditional pairs. The results of the study are supported by Motaei's (2014) findings. The findings of this study revealed better performance on four components of dictation, reading comprehension, grammar, and vocabulary in cooperative learning group in comparison to control group.

Another aim of thematic class is to increase students' motivation and to enhance quality of learning. In this area, Jovanovich and Matejevic (2014) believe that creating an environment that encourages the development of situational interest is one of the ways in which schools can encourage students' motivation, which helps students to achieve cognitive benefits in the areas, to which they are attracted at first. Similarly, Lin, Chen, and Nien (2014) found that elearning strategy is superior to the traditional learning methods with respect to students' motivation. Moreover, Rovai, Ponton, Wighting, and Baker, (2007) studied on student motivation in Traditional Classroom and E-Learning Courses. Their study results give evidence that students who are taught by e-learning are more intrinsically motivated than the students who go to Traditional Classroom. They found that there were no differences in extrinsic motivation. In this line, Kim (2006) found when visual aids were presented with graphics, students may be motivated to success and achievement in second language vocabulary.

\section{Conclusion}

In recent years, there have been basic changes in educational aids through development of technology. It is hoped that technology can change educational system in the world. These changes may include educational system of Iran with a shift of focus from traditional classes to thematic classes in schools. Such classes can motivate students for better deep learning through applying useful educational aids and cooperative learning.

The present study explored the effectiveness of two types of English thematic class on vocabulary learning in the seventh grade students of junior high school in Taybad, Khorasen e Razavi, Iran. The results of the study indicated that both types of thematic class are capable to help students learn vocabulary better and easier. Researcher of the current study reported that students of different types of thematic class showed great motivation when learning new vocabularies, and this was felt more in second type of thematic class (audio-visual aids) than first type of thematic class (visual aids).

The big difference between the students of two types of thematic class and students of traditional class could be attributed to many various reasons: First, using different educational aids could attract students' attention. Students could access and review the new words as many times as needed unconsciously. Thematic class provided EFL learners with a close-to-real-life situation. Second, the atmosphere of thematic class was interesting for students and motivated them for being in English class and learning new items deeply. The students of thematic classes expressed warm and positive feeling toward thematic class. Third, there were cooperative groups in both types of thematic class. In cooperative group learning, each student tended to take more charge of her group mates learning, and consequently it created a friendly atmosphere in the class. In short, the following conclusion can be drawn:

Both types of thematic class (whether with only visual aids or audio visual aids) had positive effect on vocabulary learning of the seventh grade students in Taybad, Khorasan e Razavi, Iran.Furthermore, in this study it can be found out whether there is a considerable difference between students' performance in two types of thematic class regarding their equipment; those were in thematic class with only visual aids and those who were in thematic class with audio visual aids. Based on results, it was found that differences between the mean scores of posttest for two experimental groups were not large enough to say that the students in audio-visual thematic class outperformed more significantly than those in visual thematic class.

\subsection{Pedagogical Implications}

Several pedagogical implications emerged from the results of the present study are mentioned in this part:

1. Students will be motivated in a new type of class. They do not suffer from traditional classes, which were boring and humdrum.

2. Students will become more active and creative.

3. Learning will become deeper and more interesting.

4. Teacher-centered methods will turn into student-centered method.

5. Teachers can plan new methods of teaching.

6. Through thematic class, the full use of technology can be possible.

7. Teaching process can be updated through technology development.

8. In general, it can be an attempt to contribute to the educational reform process. 


\section{References}

Aghazadeh, M. (2006). A Guide for New Teaching Methods. Tehran: Aeeizh.

Allahverdi Purfallah, S., \& Gholami, J. (2014).The effect of raising Iranian intermediate EFL learners' critical thinking on vocabulary learning. Social and Behavioral Sciences, 98,212-219.

Al-Seghayer, Kh. (2001). The Effect of Multimedia Annotation Modes on L2 Vocabulary Acquisition: A Comparative Study. Language Learning \& Technology, 5, 202-232.

Bahrani, T., \& Soltani, R. (2011). The pedagogical values of cartoons. Research on Humanities and Social Sciences, 1 (4), 19-22.

Baleghizadeh, S. (2012). Comparing Traditional with Cooperative Pairs: The Case of Iranian EGAP Students. Social and Behavioral Sciences, 66, 330-336. http://dx.doi.org/10.1016/j.sbspro.2012.11.275

Brown, C. (1993). Factors affecting the acquisition of vocabulary: Frequency and saliency of words. In T. Huckin, M. Haynes, \& J. Coady (Eds.), Second language reading and vocabulary learning (pp. 263-286). Norwood, NJ: Ablex

Celik, S., \& Aytin, K., \& Bayram, E. (2013). Implementing Cooperative Learning in the Language Classrooms: Opinions of Turkish Teachers of English. Social and Behavioral Sciences, 70, 1852- 1859.

Cohen, E. G. (1994).Designing group work: Strategies for heterogeneous classroom. New York: Teachers College Press

Croll, C. (1971). Teaching Vocabulary. College Composition and Communication, 22(5), 378-80. http://dx.doi.org/10.2307/356214

Daller, H., \& Phelan, D. (2007). What is in a teacher's mind? Teacher ratings of EFL essays and different aspects of lexical richness. In H. Daller, J. Milton, \& J. Treffers-Daller (Eds.), Modelling and assessing vocabulary knowledge (pp. 234-244). Cambridge: Cambridge University Press. http://dx.doi.org/10.1017/CBO9780511667268.016

Davies, P., \& Pears, E. (2003).Success in English teaching. Oxford: Oxford University Press.

Doff, A. (2004). Teach English: A Training Course for Teachers. Tehran: Payeh Danesh.

Dornyei, Z., Skehan, P., 2003. Individual differences in second language learning. In: Doughty, C., Long, M.H. (Eds.), The Handbook of Second Language Acquisition. Blackwell, Oxford, pp. 589-630. http://dx.doi.org/10.1002/9780470756492.ch18

Eisenberger, R., Pierce, W. D., \& Cameron, J. (1999). Effects of reward on intrinsic motivation: Negative, neutral, and positive. Psychological Bulletin, 125, 677-691.

Fatemipour, H. (2013). Peripheral learning of English language: A comparison between ESL and EFL contexts provided for university students. Social and Behavioral Sciences, 93, $1394 \quad-\quad 1397$. http://dx.doi.org/10.1016/j.sbspro.2013.10.050

Felder, R. M., Henriques, E. R. (1995). Learning and teaching styles in foreign and second language education. Foreign Language Annals, 28 (1), 21-31. Doi:10.1111/j.1944-9720.1995.tb00767.x

Filinezhad, N., \& JamaliNaseri, A., \& Karimi, L. (2011). On the relationship between emotional intelligence and vocabulary learning of Iranian EFL learners at the intermediate level. Social and Behavioral Sciences 28, 900-903.

Jonassen, D., H. (2008). Handbook of Research on Educational Communications and Technology: A Project of the Association for Educational Communications and Technology ( $2^{\text {nd }}$ ed). New Jersey, London: Lawrence Erlbaum Associates

Jovanovic, D., \& Matejevic, M. (2014). Relationship between Rewards and Intrinsic Motivation for Learning Researches Review. Social and Behavioral Sciences 149, 456 - 460. http://dx.doi.org/10.1016/j.sbspro.2014.08.287

Keramati, M. (2005). Collaborative Learning: Learning Through Cooperation. Mashhad: Fara Angizesh.

Kim, D. S. (2006). Effects of Text, Audio, and Graphic Aids in Multimedia Instruction on the Achievement of Students in Vocabulary Learning. (UMI Number: 3251404).

Kost, C., Foss, P., \&Lenzini, J. (1999).Textual and pictorial gloss: Effectiveness on incidental vocabulary growth when reading in a foreign language. Foreign Language Annals, 32(1), 89-113.

Krashen, S. D. (1987). Principles and practice in second language acquisition. UK: Prentice-Hall International English Language Teaching.

Latragna, Ph. A. (1997). The impact of gender and race perceptions of classroom interactions, instruction, and curriculum: A multicultural perspective. Dissertation Abstract International, 58(10), 253. (UMI No. 9812113).

Laufer, B., \& Hulstijn, J. H. (2001). Incidental vocabulary acquisition in a second language: the construct of taskinduced involvement. Applied Linguistics, 22(1), 1-26. http://dx.doi.org/10.1093/applin/22.1.1

Lawson, M. L., \& Hogben, D. (1996). The vocabulary-learning strategies of foreign-language students. Language Learning, 46(1), 101-135. http://dx.doi.org/10.1111/j.1467-1770.1996.tb00642.x 
Levin, J. R., Anglin, G. J., \& Carney, R. N. (1987). On empirically validating functions of pictures in prose.In D. M. Willows \& H. A. Houghton (Eds.), The psychology of illustrations: Basic research 51. New York: Speringer-Verlag. http://dx.doi.org/10.1007/978-1-4612-4674-9_2

Lin, H. M., Chen, W. J., \& Nien, S. F. (2014). The Study of Achievement and Motivation by e-Learning - A Case Study. International Journal of Information and Education Technology, 4, 421-425. http://dx.doi.org/10.7763/IJIET.2014.V4.442

May, E. (2000). Innovation in Large Lectures Teaching for Active Learning. Bioscience, American Institute of Biological Sciences, 47.

Mayer, E., \& Sims, K. (1994). For whom is a picture worth a thousand words? Extensions of a dual-coding theory of multimedia learning. Journal of Educational Psychology, 86(3), 389-401. http://dx.doi.org/10.1037/0022-0663.86.3.389

Mediha, N., \& Enisa, M. (2014). A Comparative Study on the Effectiveness of Using Traditional and Contextualized Methods for Enhancing Learners' Vocabulary Knowledge in an EFL Classroom. Social and Behavioral Sciences, 116, 3443-3448. Doi:10.1016/j.sbspro.2014.01.780

Motaei, B. (2014). On the Effect of Cooperative Learning on General English Achievement of Kermanshah Islamic Azad University Students. Social and Behavioral Sciences http://dx.doi.org/10.1016/j.sbspro.2014.03.540

Mulalic, A., Mohd Shah, P., \& Ahmad, F. (2009). Perceptual learning style of ESL students. European Journal of Social Sciences, 7(3), 101-113.

Nelson, D. L., Reed, V. S.,\& Walling, J. R. (1976). The pictorial superiority effect. Journal of Experimental Psychology: Human Learning and Memory, 2, 523-528. http://dx.doi.org/10.1037/0278-7393.2.5.523

Newby, J., Stepich, A., Lehman, D., \& Russell, D. (1996). Instructional technology for teaching and learning: Designing instruction, integrating computers, and using media. Englewood 422.

Nili, M., \& Altafi Dadgar, F. (2011). What Is Mobile Learning? Tehran: Omid.

Olive, P. (1972). The Secondary School Today. New York.

Olsen, R., \& Kagan. S. (1992). About cooperative learning. In C. Kessler (ed.), cooperative language learning: $A$ Teacher's Resource Book. New York: Prentice Hall. 1-30.

Oxfored, R., \& Crookall, D. (1990). Vocabulary learning: “A critical Analysis of techniques.” TESL Canada Journal, $7(2), 9-30$.

Rasul, S., \& Bukhsh, Q., \& Batool, Sh. (2011). A study to analyze the effectiveness of audio visual aids in teaching. Social and Behavioral Sciences, 28, $78-81$.

Rieber, L. P. (1994). Computers, graphics, and learning. Madison, WI: WCB Brown \& Benchmark.

Richards, J.C. (2009). Curriculum Development in Language Teaching. Tehran: Rahnama. http://dx.doi.org/10.1017/CBO9780511667220

Richard, J. C., \& Rodgers, T. S. (2001).Approaches and methods in language teaching. Boston, MA: Cambridge University Press. http://dx.doi.org/10.1017/CBO9780511667305

Reinders, H., \& White, C. (2010). The Theory and Practice of Technology in Materials Development and Task Design. In N. Harwood. English Language Teaching Materials: Theory and Practice (pp. 58-80). United States of America: Cambridge University Press.

Rovai, A., Ponton, M., Wighting, M., Baker, J. (2007). A Comparative Analysis of Student Motivation in Traditional Classroom and E-Learning Courses, International Journal on E-Learning, 6 (3), 413-432.

Rule, A. C., \& Auge, J. (2005). Using humorous cartoons to teach mineral and rock concepts in sixth grade science class. Journal of Geosciences Education, 53(3), 548-558.

Shafer, I. (2002). Team Teaching. University of Science and Arts of Oklahama: Web-edition.

Shepard, R. N. (1978). The mental image. American Psychologist, 33, 125-137. http://dx.doi.org/10.1037/0003066X.33.2.125

Singh, Y. K. (2005). Instructional Technology in Education, published by Daryaganj new Dehli.

Slavin, R. (1987). Co-operative learning. The Elementary School Journal, 88.

Snyder, H., \& Colon, I. (1988). Foreign language acquisition and audio-visual aids. Foreign Language Annals, 21(4), 343-384. http://dx.doi.org/10.1111/j.1944-9720.1988.tb01079.x

Williams, M., \& Burden, R.L. (2000). Psychology for Language Teachers: A Social Constructivist Approach. United Kingdom: Cambridge University Press. 